\title{
The origin, function and disappearance of the "Twelve": Continuity from Jesus to the post-Easter community?
}

\author{
Dietrich-Alex Koch ${ }^{1}$ \\ Westfälische-Wilhelms Universität, Münster (Germany) \\ Visiting Professor: University of Pretoria
}

\begin{abstract}
The group of the Twelve is mentioned 28 times in the Synoptic Gospels. However, the Evangelists were not familiar with the historical role of the Twelve. Even the pre-Easter origin of Matthew 19:28/Luke 22:30 is debatable. On the other hand 1 Corinth 15:3b-5 provides a solid basis for the assumption of a pre-Easter origin of the Twelve. They functioned as a group representing the twelve tribes of Israel as the eschatological people of God. Reaffirmed in this role by the risen Lord they had for a short time a leading role in the early Christian community in Jerusalem. But their importance soon declined because after a short time the twelve former disciples from Galilee could no longer be representative of a rapidly expanding community. In the last decades of the first century the Twelve got a new importance on the literary level of the Gospels.
\end{abstract}

When we are dealing with history we are always involved with the reconstruction of history. This applies to all history, not only the history of Early Christianity. While this may be regarded as a disadvantage, it is

\footnotetext{
${ }^{1}$ Prof Dr Dietrich-Alex Koch from the Neutestamentliches Seminar, Evangelisch-Theologische Fakultät, Westfälische-Wilhelms Universität, Münster, Germany, is a research associate of Prof Dr Gert J Steyn, Department of New Testament Studies, University of Pretoria. This article is based on the lecture delivered at the "Conference on Early Christianity: Continuity Changes - Breaks. Problems of reconstructing the history of Early Christianity", hosted by the Theological Faculty of the University of Pretoria at Hammanskraal, on $25^{\text {th }}$ and $26^{\text {th }}$ August 2004. It was an honour to have been invited to this conference by the Faculty of Theology and I wish to thank the Dean, Prof Cas Vos, and all colleagues and participants for the warm hospitality. The conference was a very fruitful experience for me and I thank Prof G J Steyn who was responsible for all the arrangements for the meeting and chaired the discussions. Additionally, I had the opportunity to read the paper on $24^{\text {th }}$ August 2004 at the Faculty of Arts at the Rand Afrikaans University, now University of Johannesburg, and I want to thank Prof J A du Rand and all colleagues and students I met both at the University of Johannesburg and at the conference in Hammanskraal for the fruitful discussions which I found most helpful. Richard Ascough, Associate Professor for New Testament at Queen's University, Kensington Ontario (Canada), who stayed for a sabbatical in Münster, sponsored by the HumboldtFoundation, helped me with the English editing of the article. All readers of the paper will profit from his labour. He was the first reader of my draft and gave me helpful comments. The responsibility, however, for the result is naturally not his.
} 
inevitable but important in order to understand the reason for this fundamental issue. $^{2}$

What is necessary if we want to describe the history of South Africa of the past 200 years, that of Central Europe during the middle Ages, or the history of medicine in the $19^{\text {th }}$ century? First of all, we have to choose a subject and, simultaneously, the specific period of time within which we want to explore the history of the chosen subject. Next, we must collect all facts within this period that are related to the subject. Finally, we have to connect these facts, and at this stage it is necessary to assess the importance of the facts in relation to each other. Which facts have fundamental importance, and which facts are to be understood as a result of another, more fundamental fact? If we want to write history, we have to establish the main developments of the subject we are dealing with, and the main reasons for such development. In doing so, the individual facts no longer are isolated units without any further importance for other facts. Rather, they become part of a comprehensive picture. Writing history involves producing a network between and behind the facts. This, in turn, provides a framework within which we can perceive the interrelation among the facts. It is only by this act of interpretation that we can comprehend the importance of the facts. This does not mean that writing history is akin to writing a fictional story. Not at all. The network cannot be produced arbitrarily. It is a network which has to explain the importance of the facts. Facts and the network in terms of which we reconstruct interrelations and developments must fit together.

To summarise it in a single sentence: History is not a collection of facts with attached interpretations; on the contrary, history is only achieved through interpretation. ${ }^{3}$ This applies to all areas of history - and it applies to all periods in which historians try to write history. It applies to modern historians, but also to Herodotus, the father of historical writing.

By briefly examining the work of Herodotus, it becomes clear that these problems had already been at hand at the very beginning of historical writing. Herodotus who lived in the second half of the $5^{\text {th }}$ century $\mathrm{BC}$, tried to report on the central political event that dominated the last two generations of his own cultural and political world: the war between the Persians and the Greeks. In

\footnotetext{
${ }^{2}$ As this was the first paper of the Conference in Hammanskraal, I started with some general remarks on the problem of reconstructing history.

${ }^{3}$ The famous German historian Leopold von Ranke (1795-1886) claimed that all historical research has to describe history "as it really has been." But the discussion on "historicism" in the $19^{\text {th }}$ and $20^{\text {th }}$ century clearly showed that reconstruction of history inevitably is interpretation. For this discussion see Rebenich (2000:469-485). In the area of New Testament research the most famous example is the debate about the "historical Jesus", rooted in the $19^{\text {th }}$ century and which is still ongoing. For the actual discussion on historicism see Rüsen $(1983,1986)$ and Goertz (1995).
} 
attempting this account, what was Herodotus' aim? In the first sentence of his work, the so-called prooemium he provides an explanation:

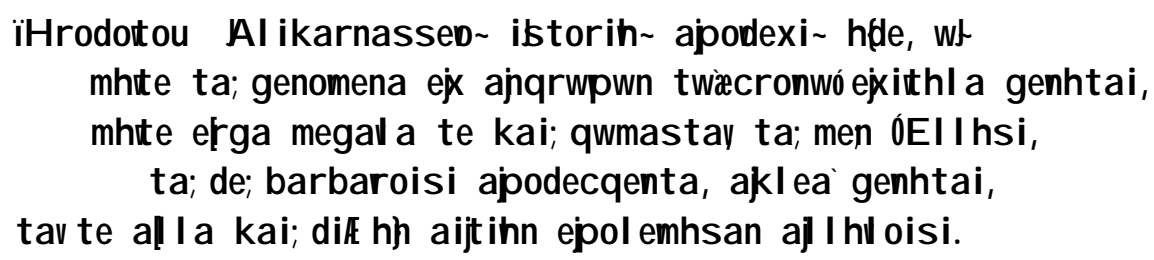

This is the exposition of the inquiry of Herodotus of Halikarnassos, in order that

neither things, which have happened by men, will fade away in the course of time

nor great and marvellous deeds done by Greeks or

Barbarians will become inglorious

and especially by which reason they waged war against each other.

This opening sentence reveals two different ways of dealing with events of the past. The middle of the sentence, in other words the two indented lines, give expression to the older concept of heroic tales or poems. These heroic tales or poems have as subject "things, which have happened by men" / $\mathrm{t}$; genomena ex anq rwpwn. This subject is specified in the next line where Herodotus speaks of "great and marvellous deeds" I el ga mega va te kai; q wmas t a y These "great and marvellous deeds" are the subject of poets such as Homer and his anonymous predecessors. The poets' aim is to remember these deeds - they shall "not fade away in the course of time nor become inglorious." To remember the glory of the deeds of the past means to prevent these deeds from being forgotten. ${ }^{4}$

Besides this older concept, a new approach to the events of the past is also evident. At the end of the prooemium Herodotus states that the aim of his book is to provide the "reason" or "cause", the a if i a , for the war between the Greeks and the so-called Barbarians. And at the very beginning of the prooemium Herodotus himself classifies the task he sets out to undertake as "exposition" (a podexi $\sim$ ) of what he calls "history". But is t or i in in this early use does not mean "history" in the later technical sense of the word. Rather, as

\footnotetext{
${ }^{4}$ For Homer and the other epic tales of the archaic epoch, see Lendle (1992:3-9).
} 
the verb is t or ei n' indicates, it means "inquiry"; is t or i h a p odexi therefore must be rendered by "the exposition of his knowledge obtained by inquiry."

Thus, Herodotus is aware of the fact that if he wants to explain the cause, the a it i i of the war between the Greeks and the Persians, his undertaking goes far beyond the task of recounting the fame and the glory of great persons of the past. ${ }^{6} \mathrm{He}$ wants to detect the reason for an important political development which affected two great peoples and two great cultures in the last two generations. In order to do so, he has to acquire thorough knowledge of many facts and collect a host of information about foreign countries and cultures, as well as about the political developments in Greece. But not only does he have to collect this data, ${ }^{7}$ he is forced to put these facts in relation to each other and to create a coherent picture in which the collected facts have their distinctive place.

It is not possible to deal with the history of writing history from Herodotus to his successors Thucydides and Polybios and the Roman Historians in this paper. It is nevertheless important to bear in mind the basic problems associated with writing history when we turn to the challenge of reconstructing the history of Early Christianity.

As far as the reconstruction of the history of Early Christianity is concerned, the problem of continuity and discontinuity between the pre-Easter und post-Easter period is a crucial point. In this respect the origin, function and disappearance of the Twelve is a very interesting example. But first of all it has to be recognised that a problem of continuity exists at all. We have, someone may object, a clear picture in the Gospels that Jesus installed the Twelve, that they followed him in Galilee, that they shared his ministry and that they followed him on his way from Galilee to Jerusalem. That is indeed the picture drawn in the Gospel of Mark and the other synoptic gospels, those

\footnotetext{
${ }^{5}$ Lateiner (1989:9): "Historie, apodexis and aitie were relatively new terms: Herodotus draws attention to his invention. A p odexi is t or ih suggests that the written report is at least two steps removed from t a; genomena, the events ... His report cannot replicate the events itself, ... nor is his report all the accounts that he heard, all the research that he conducted, for even the most restrictive annalist assimilates, digests, discards, reorders his assembled notes and datas. His report is the production-display-performance-proof-declaration-publication of his labours, to put it awkwardly but more adequately."

${ }^{6}$ For the prooemium of Herodotus, see Meister (1997:243) who emphasises another aspect: Herodotus restricts his investigation to the deeds of men, thus excluding the tales of Gods and heroes. In comparison to the works of his predecessors, especially Hekataios of Milet, this is indeed another important step, but it does not rule out that Herodotus was the first to have enquired about the "cause", the a it i a of a historical development.

${ }^{7}$ The work of Herodotus contains a lot of ethnographical and historical material, especially in the first books. Scholars argued therefore that he first started as an ethnographical writer, and that the development to a historian still can be seen in his work. But it is easy to explain that the ethnographical material is mainly to be found in the first half of his work and it is clearly linked with the work as a whole (cf Meister 1998:469-475).
} 
of Matthew and Luke. But a critical review of the individual texts in which the Twelve are mentioned, provide reasons for doubting whether this group of twelve disciples had a pre-Easter origin. ${ }^{8}$ Even in the most prominent text concerning the Twelve, the installation of the group of the Twelve in Mark $3: 13-19^{9}$, this is the case.

\begin{tabular}{|c|c|}
\hline 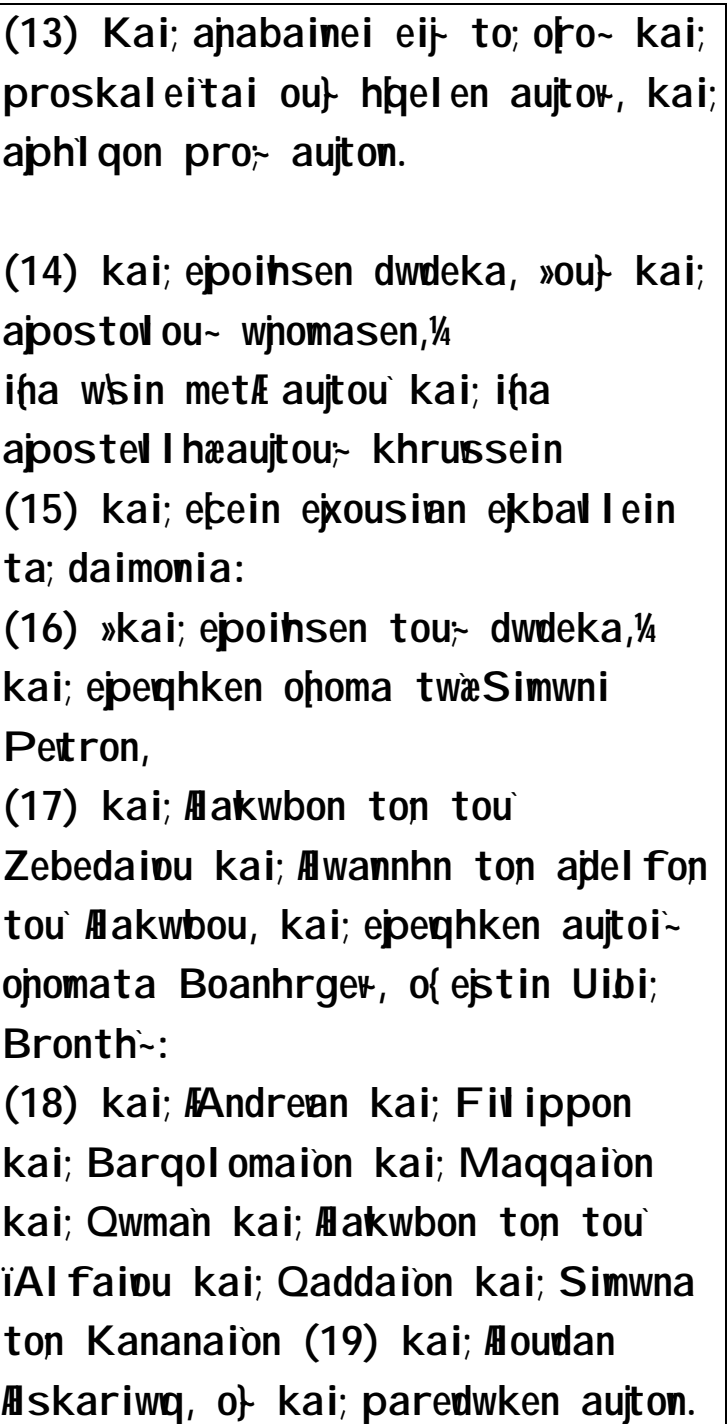 & $\begin{array}{l}\text { (13) He went up the mountain and } \\
\text { called to him those whom he } \\
\text { wanted, } \\
\text { and they came to him. } \\
\text { (14) And he made twelve, [whom he } \\
\text { also named apostles], } \\
\text { to be with him, and to be sent out to } \\
\text { proclaim the message, } \\
\text { (15) and to have authority to cast out } \\
\text { demons. } \\
\text { (16) [So he made the twelve]: and } \\
\text { to Simon he gave the name Peter; } \\
\text { (17) and James (son) of Zebedee and } \\
\text { John the brother of James and } \\
\text { he gave them the name Boanerges, } \\
\text { that is, Sons of Thunder; }\end{array}$ \\
\hline
\end{tabular}

\footnotetext{
${ }^{8}$ The problem is much debated, at least since Bultmann (1931:65, 366, 369-370; 1958:39-40, 62) questioned the pre-Easter origin of the traditions concerning the Twelve. For the further discussion, see Klein (1961); Stock (1975); Trilling (1977:201-222); Best (1978:11-35); Holtz (1980:874-880); Klauck (1989:131-136); Schenke (1990:75-78); Roloff (1993:61-62); Koch (1995:1-20); Theissen \& Merz (1997:200f); Meier (1997:635-672); Koch (forthcoming). For a fuller bibliography of German literature, see Trilling (1977:221-222). For a more expanded bibliography of English literature, see Meier (1997:637). Meier (1997:635) points out that there are also up-to-date arguments supporting the view that the Twelve cannot be traced back to Jesus. Referring to John Dominique Crossan, Meier says: "Scholars who think of Jesus in terms of a wandering Cynic philosopher, expounding a first-century version of egalitarianism and feminism tend to deny the existence of the circle of the Twelve during Jesus' lifetime."

${ }^{9}$ New Testament translations are adapted from the NRSV.
} 
According to the preceding text, Mark 3:7-12, Jesus is surrounded by a huge crowd and by his disciples. Mark does not mention how many disciples were present, but in Mk 3:13 it is clear that Jesus singles out a limited number of persons who belong to a greater group of disciples. And then Mark says: "He made Twelve" / kai; ep oiths en dwdeka. That is a rather vague expression, and upon further investigation, the problems will increase. The crucial question is: What is the function of these "Twelve"? Mark provides two functions (3:14, 15):

- they should be "with him",

- it is their duty to be sent out for proclamation and for casting out demons.

This twofold function of the "Twelve" does not explain the choice of 12 persons. Concerning the first function mentioned by Mark, we get no explanation why it was necessary for Jesus to have this group at all. Moreover, there is no explanation why it had to be a group of 12 members to be "with him" - rather than 10 or 15 or 25.

The same applies to the second function, the ministry of preaching. This task doesn't explain the reason for the number of 12 either. This is also evident in comparison with Luke 9 and Luke 10. In Luke 9:1 we have the commissioning of the "Twelve" to preach and to cast out demons. In Luke 10 there is a second text commissioning the disciples to heal the sick and proclaim that the Kingdom of God has come near. The reason for the twofold commissioning is obvious: In chapter 9 Luke reproduces the commissioning of the Twelve that he had found in Mark 6. In chapter 10 he reproduces a similar tradition he had found in the Sayings Source Q. In the latter text Luke states that Jesus sent out 72 disciples. But in neither text does Luke explain why the groups are of the size specified. Returning the attention to Mark, I think it can be reasonably assumed that at its historical outset the group of the Twelve had a function that was connected to the number of 12 - but it is obvious that Mark is no longer familiar with this function. Therefore, we have to conclude that the only pre-Markan tradition in Mark 3:13-19 is the list itself of the Twelve in verses $16-19 .{ }^{10}$

In examining this list, ${ }^{11}$ we may be inclined to conclude that it is of preEaster origin, because at the very end of the list Judas is mentioned, who, as

\footnotetext{
${ }^{10}$ For a detailed analysis of the vocabulary in Mark 3:13-16a, which turns out to be characteristically Markan, see Stock (1975:7-53).

${ }^{11}$ Mark connects the list of the Twelve with traditions concerning the bynames of some members. The result is in some way an awkward syntactical structure.
} 
it is explicitly stated, betrayed Jesus. One might think that in a post-Easter situation it would be impossible to invent a list of Jesus' special disciples that includes the one that betrayed him. But there are two reasons why we should be cautious:

- As we have noted, it is clear as early as Mark's gospel that the writer had no idea what the original function of the Twelve was, and we will see that the group of the Twelve very soon disappeared in the history of the Christian community in Jerusalem, long before the Gospel of Mark was written.

- There is ample evidence that harsh expressions against the disciples originated in post-Easter times.

In Mark 6:52 Mark comments on the disciples after the miracle of the loaves and the walking on the sea with the following words:

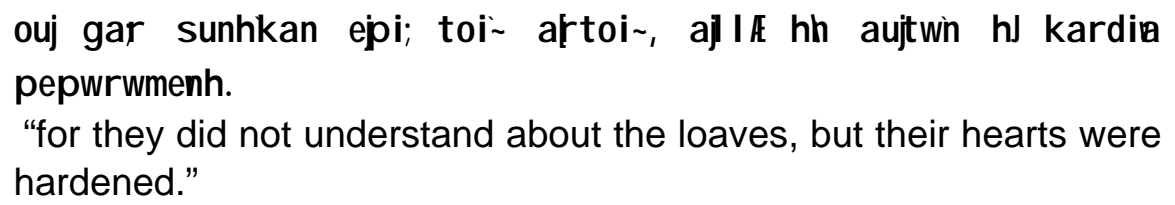

This is the type of criticism we would expect to be levelled at the enemies of Jesus, not at his disciples. And in this case it is clear that this critical remark is a comment of Mark himself (Koch 1975:107-108; Gnilka 1978:265-267).

Even more striking is a sentence in the letter of Barnabas, belonging to the so-called Writings of the Apostolic Fathers, and written between 130 and 132 AD (Prostmeier 1999:117-118). Barn 5:9 reads (translation by Kraft 1965:94-95):

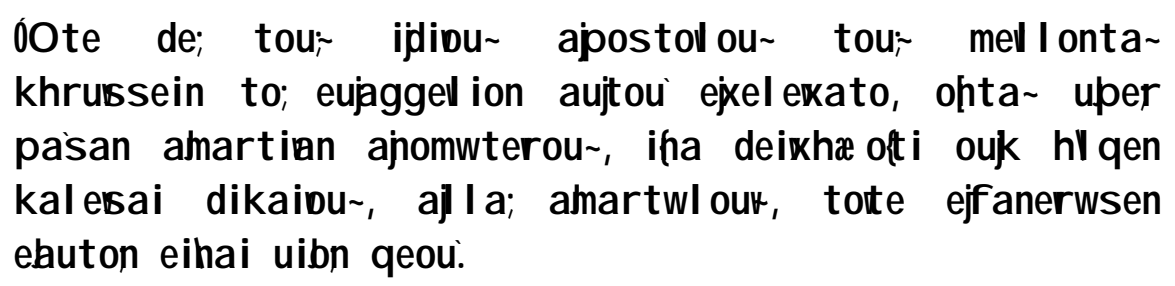

But when he chose his own apostles who were destined to preach his gospel - men who were sinful beyond measure, so that he might prove that he came "not to call righteous but sinners" - it was then that he revealed himself as God's son.

If a similar text where Jesus would say: "I chose you, who are sinful beyond measure, because I have not come ..." and so forth, had to appear in one of 
the Gospels, then most of us would not hesitate in judging it to be impossible to invent such a negative statement (applying the criterion of the difficulty of the saying). But Barn 5:9 demonstrates that it is possible to make such slanderous remarks about the disciples in the post-Easter context. It is sufficient to assume that the Judas' betrayal is a historical event and that, when the list of the Twelve was produced in later times, he was included in this list because he belonged to the inner circle of the disciples of Jesus.

Therefore we have to look for other texts referring to the group of the Twelve. In the Gospel of Mark mention is made of the Twelve in a further nine texts (Mk 4:10; 6:7; 9:35;10:32; 11:11; 14:10, 17, 20,43), in all of which the Twelve do not form part of a pre-Markan tradition, but are part of the editorial framework. In 4:10; 9:35; 10:32 Mark creates episodes which depict Jesus as an esoteric teacher: Here Mark uses the Twelve as a limited audience of Jesus. During Jesus' last days in Jerusalem he also uses the Twelve as a group which accompanied Jesus initially, but failed and abandoned him later on. That Jesus was abandoned by his disciples is part of the pre-Markan narration of the Passion, but the emphasis on the Twelve is part of the comprehensive literary activity of Mark. ${ }^{12}$

There is only one tradition in the Synoptic Gospels where the group of the Twelve is possibly part of the tradition itself, namely in Matthew 19:28 (parallel Lk 22:28-30). There is a common tradition that underlies both texts; this tradition mentions the 12 tribes of Israel - and Jesus' announcement that his followers will "judge" the 12 tribes of Israel.

\begin{tabular}{|c|c|c|}
\hline Mt 19, 28 & $\begin{array}{l}\text { Q (hypothetical } \\
\text { reconstruction) }\end{array}$ & Lk 22, 28-30 \\
\hline 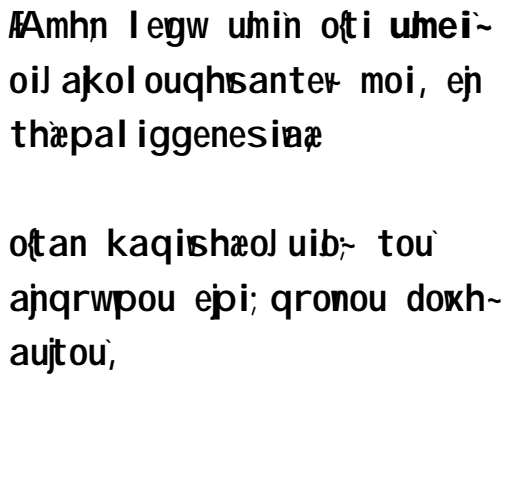 & $\begin{array}{l}\text { umei } \sim \text {... } \\
\text { oil akol oughsant eł moi ... }\end{array}$ & 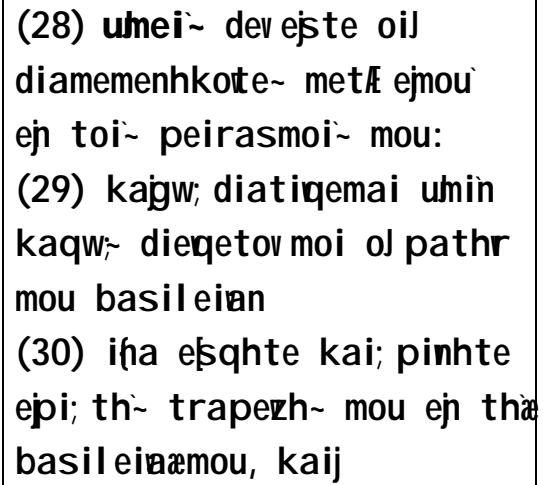 \\
\hline
\end{tabular}

\footnotetext{
12 The same applies to the Gospels of Matthew and Luke: Matthew 10:1, 2, 5; 19:28; 20:17; 26:14, 20, 47 are clearly from Mark; Matthew 11:1 is the closing of the speech to the disciples created by Matthew; Luke 9:1; 18:31; 22:3, 47 are from Mark; Luke 8:1 and 9:12 are created by Luke; there is only one exception: Matthew 19:28 / Luke 22:30.

${ }^{13}$ See Robinson (2000:558-561); there is only one, but important difference: Robinson et al omit "twelve" before "thrones" (following Lk), while in the following paragraph I will argue in favour of "twelve thrones" (thus following Mt). Therefore I included "twelve" before "thrones" in brackets.
} 


\begin{tabular}{|c|c|c|}
\hline $\begin{array}{l}\text { kaqhosqe kai; umei } ~ \\
\text { epi;dwdeka qrouou } \\
\text { krinonte tardwdeka } \\
\text { fulart tou Assrahv. }\end{array}$ & $\begin{array}{l}\text { kaqhsesqe } \\
\text { eji; »dwdek a } 1 / 4 \text { qronou } \\
\text { ta } ; \text { dwdek a f ul a } r \\
\text { krinont e } \sim \text { t ou Es rahb. }\end{array}$ & $\begin{array}{l}\text { kaqhosqe } \\
\text { eji; qronwn } \\
\text { tar dwdeka ful ar } \\
\text { krinonte t ou Esrahb. }\end{array}$ \\
\hline $\begin{array}{l}\text { (28) Jesus said to them: Truly } \\
\text { I tell you, } \\
\text { you who have followed me, } \\
\text { at the renewal of all things, } \\
\text { when the Son of Man is } \\
\text { seated on the throne of his } \\
\text { glory, you } \\
\text { will also sit on twelve thrones, } \\
\text { judging the twelve tribes of } \\
\text { Israel. }\end{array}$ & $\begin{array}{l}\text { will sit on [twelve] thrones } \\
\text { judging the twelve tribes of } \\
\text { Israel. }\end{array}$ & $\begin{array}{l}\text { (28) You are those who have } \\
\text { stood by me in my trials; (29) } \\
\text { and I confer on you, just as } \\
\text { my Father has conferred on } \\
\text { me, a kingdom, (30) so } \\
\text { that you may eat and } \\
\text { drink at my table in my } \\
\text { kingdom, and } \\
\text { you will sit on thrones judging } \\
\text { the twelve tribes of Israel. }\end{array}$ \\
\hline
\end{tabular}

Two crucial questions are related to the reconstruction and evaluation of this logion:

a. Is the mentioning of the 12 thrones in Matthew original to the $\mathrm{Q}$ saying? This being the case, we would have a clear allusion to the group of the Twelve within an early tradition;

b. Is this a pre-Easter tradition?

Regarding question a: I am of the opinion that there are good reasons to assume that Luke omitted mentioning the explicit number of the thrones. He placed this logion at the end of a pericope dealing with the problem of precedence among the disciples (22:24-30) and this pericope follows directly after the prediction of Judas' betrayal (22:21-23). It would be inappropriate to announce directly thereafter that Judas would sit on one of the thrones in the Kingdom of the Lord. Therefore, despite the decision of the International Qproject, it is more probable that the Q-tradition contained the explicit mentioning of the twelve thrones, rather than the opposite assumption. ${ }^{14}$

The reasons for the opposite view, namely that Matthew inserted the "Twelve" before "thrones" are as follows (Heil 1998:422-425):

i. By inserting Matthew 19:28 in the text of Mark 10:29, Matthew stresses the role of Peter as spokesperson of the Twelve. This is in

\footnotetext{
${ }^{14} \mathrm{~A}$ considerable number of scholars argue that the explicit mentioning of the "twelve" before the "thrones" has been omitted by Luke, see Schulz (1972:332); Fitzmyer (1984:1419); Luz (1997:121).
} 
fact the result, but does it prove that the explicit mentioning of twelve thrones in 19:28 is added by Matthew?

ii. Dwdeka (and the concept of 12 disciples at all) does not occur elsewhere in Q. But this argument is not convincing either: It is an argumentum e silentio and therefore rather weak. ${ }^{15}$

We can thus conclude that there are good reasons for assuming that the common tradition of the logion used by Matthew and Luke clearly referred to the Twelve.

Regarding the second question: It is rather doubtful that this logion goes back to Jesus. The underlying concept of a final judgement of Israel is in accordance with traditions of Q critical of Israel, ${ }^{16}$ especially those passages that contain accusations against "this generation" / h/ g enea; a u $\mathrm{k} h{ }^{17}$

On the other hand, tracing this logion back to the historical Jesus is not easy. Scholars refer to PsSal 17:26 (Theissen \& Merz 1997:200), where to "judge" is indeed a prominent task of the expected king, the son of David:18 But upon closer examination, this text demonstrates how it fundamentally differs from the message of Jesus: The expected son of David in PsSal 17 shall perform justice and cast out the unjust, that is t a ; ef nh (17:23-25), he shall purify Jerusalem (17:22) and within the sanctified people he shall dispose all "injustice" (17:27). The underlying concept of ritual purity cannot be reconciled with the attitude of the historical Jesus. ${ }^{19}$

\footnotetext{
15 The weakness of this argumentum e silentio is sharply emphasized by Meier (1997:659): "In short, since the scarcity - or even absence! - of references to the disciples of Jesus in Q leads no one to deny the existence of such a group, the same should hold true of the one reference to the Twelve."

${ }^{16}$ Luke 10:13-16 / Matthew 11:20-24; Luke 11:37-54 / Matthew 23:1-36; Luke 13:28f / Matthew 8:11-12.; Luke 13:34-35 / Mt 23:37-39.

${ }^{17}$ Luke 7:31-35 / Matthew 11:16-19; Luke 11:29-32 / Matthew 12:38-42; Luke 11:49-51 / Matthew 23:34-36; for this concept see Tucket (1996:196-201).

${ }^{18} \mathrm{~K}$ r i mein is part of the concept of kingship, but not an equivalent to a [ c ei $\mathrm{n}$, see Luz (1997:129, n 71). Fitzmyer: Lk 14:19 tries to interpret k r inein in a broader sense.
}

${ }^{19}$ In her monograph Eschatologische Mitherrschaft, Hanna Roose (2004:53-57) tries to establish a fixed use of $\mathrm{k}$ rimein as expression of beneficial rule. Thus, it would be possible to trace Matthew 19:28 back to the historical Jesus. But k ri mein as an aspect of rule or kingship implies the punishment of the unjust and to expel the unclean. This applies not only to PsSal 17, but also to 1 Makk 9:73: kai; h[xat o J wnaqan krimein ton I a on kai; hf anisen tou; aś ebei $\sim$ ej J srahv ("and Jonathan began to judge the people, and he expelled the ungodly out of Israel"). The difference between k rimein ("to judge") and ba s il euein ("to rule") can clearly be seen in 1 Corinthians: In 1 Cor 6:1-2 is dealing with the power of the saints to judge ( $\mathrm{k}$ r imein) the world (and the angels), whereas in 1 Cor 4:8 Paul ironically states "Quite apart from us you have become kings (epas il eus a te)!" 
Despite the negative result as far as the origin of this logion is concerned, one positive conclusion can be drawn from it: In this tradition we have a clear relation between the number of the Twelve and the concept of the 12 tribes of Israel - and this presents the only possibility to understand the original function of the "Twelve".

Let us now turn our attention to 1 Corinthians 15:3-5, the oldest nongospel tradition in which the group of the Twelve is mentioned. It is remarkable that both the advocates and opponents of a pre-Easter origin of the "Twelve" refer to this text. ${ }^{20}$

1 Corinthians 15:3-5

(3) paredwka gar umiǹ ej prwtoi , o\}kai; parevabon, oł̣i Cristo; apeqanen uper twh̀ amartiwǹ hmwǹ kata; tai graf a

(4) kai; ofi et af $h$, kai; oki eghgertai thæhmera hærithækata; ta; grafa (5) kai; oki wf qh Khfa æeita toi d dwdeka:

${ }^{3}$ For I handed on to you as of first importance what I in turn had received: that Christ died for our sins in accordance with the scriptures,

${ }^{4}$ and that he was buried, and that he was raised on the third day in accordance with the scriptures, ${ }^{5}$ and that he appeared to Cephas, then to the twelve.

The tradition of which the pre-Pauline origin is indisputable ${ }^{21}$ includes in the last line (verse 5) a statement about Peter and the Twelve and the appearance of the risen Lord. According to this tradition Peter is the one to whom the risen Lord appeared first - and then to the Twelve. The appearance to the Twelve is only possible on the precondition that they had gathered in this number - or at least as a group called "The Twelve". In addition, it is plausible to assume that this assembly was called together by Peter after his own experience of the risen Lord. Up to this point, there is little dispute among scholars. But now the question arises: Why did Peter, after his own experience of the risen Lord, call together a group of twelve disciples - and not 25 , or for that matter all the disciples gathered in Jerusalem? By calling together a group of twelve at least implies a basic idea of the people of God represented by this body of 12 disciples.

\footnotetext{
${ }^{20}$ For a supportive view, see Holtz (1980:877-878); Roloff (1993:61-62). A critical position is for example held by Schneemelcher (1981:61-62); Schenke (1990:76).

${ }^{21}$ For analysis of the tradition see Fee (1987:722-729); Schrage (2001:31-53). Concerning the mentioning of the Twelve in 1 Corinth 15, Meier (1997:670) rightly speaks of a "fossil of reference" and he is correct as well, when he argues that this applies already to Paul himself: Against the background of the total absence of the Twelve in the Pauline writings this is "the sole exception that proves the rule."
} 
The alternative that emerges as a result goes as follows:

a) Peter re-gathered the pre-Easter group of the Twelve which had been installed in pre-Easter times by the historical Jesus; or

b) Peter created the idea of the Twelve and he consciously gathered a group of 12 disciples without any precondition in the ministry of the historical Jesus.

In my judgement, the former is the more probable possibility, in other words that Peter re-gathered a pre-Easter group of 12 disciples. Otherwise, we would have to explain how the ecclesiological concept of the people of God, represented by the Twelve, directly emerged from the basic christological conviction that God had raised Jesus from the dead.

If this conclusion were acceptable, the next step to secure this result would be to determine the function of the Twelve within the ministry of Jesus, and subsequently to inquire about their historical role in the first decades of the post-Easter community in Jerusalem.

Four statements or assumptions are possible concerning the role of the Twelve within the ministry of Jesus (Becker 1996:33-34; Theissen \& Merz 1997:201):

i. The installation of the group of the Twelve is an expression of the fact that with his message Jesus addressed himself to Israel as a whole.

ii. This Israel to which Jesus addressed himself went far beyond the limits of the present empirical Israel which in reality comprised only two tribes. When Jesus referred in his ministry to the 12 tribes of Israel this implies that he expected the eschatological restoration of Israel as a whole.

iii. The installation of the Twelve did not mean that Jesus had started to build a holy remnant as was the case at Qumran. On the contrary, his most characteristic activities, especially his eating with tax-collectors and "sinners" prove that he did not accept any border or separation within the people of God.

iv. Thus, we can conclude: In Jesus' ministry, that is in his healing activities, in his meal community and in the proclamation of the E UAGGELION to the poor, the vision of the eschatological people of 
God started to become a reality, the visible expression of which was the installation of the Twelve.

This development abruptly came to a halt with the crucifixion of Jesus. The crucifixion demonstrated that the ministry of Jesus had failed. There was thus no possibility for a continuation of the group of the Twelve. The possibility of continuation only emerged when a completely new action of God was proclaimed, namely that God had not abandoned Jesus, but had in fact raised him from death whereby the risen Lord thus obtained heavenly status. This message implied that Jesus had not failed in his ministry, as his enemies had maintained, and therefore it was possible to re-convene the group of the Twelve. And naturally they gathered as the former Twelve, despite actually only being eleven.

The group of the Twelve, re-convened by Peter, was re-installed by the appearance of the risen Lord and so their function, namely to form the nucleus of the new people of God, was confirmed. But this new people of God now gathered on a new basis: They gathered in the name of the risen Jesus. And this new people of God started in the circle of those who believed that God had raised Jesus from the dead ( $\mathrm{Rm} \mathrm{10:9)}$ and who proclaimed in the worship the exalted Jesus as "Lord" (1 Cor 12:3). The group of the Twelve re-gathered by Peter and authorised by the risen Lord, formed the nucleus of this new people of God (Roloff 1993:61),

If this reconstruction of the history of the Twelve is plausible, then we can assume that the by-election of Matthias (Ac 1:15-26) to replace Judas is basically reliable. Against this background it is particularly interesting to note that this was indeed the only by-election of a member of the Twelve. When John, son of Zebedee, was killed by Herodes Antipas (41-44 AD) he was not replaced by another disciple (Ac 11:1-3). This raises the question: Why did the Twelve disappear so quickly from the stage of history?

In my opinion it was the very success of the group of the Twelve that made it obsolete as representative body of the community in Jerusalem. The members of this group were all disciples of the historical Jesus, that is they formerly lived in Galilee. The same applied to all the other members of the community, because at the very beginning, we have to assume, there were at best very few members who did not come from Galilee. At this stage the Twelve indeed were a representative body for the community as a whole. But this did not last very long. The community grew fast, new members joined of which at least two groups can be identified: 
- People of Galilee who weren't disciples of the historical Jesus now became members of the community in Jerusalem and settled there. We know James, the brother of Jesus, and Mary, his mother by name, but it can be assumed that other people from Galilee, who were not as prominent as James or Mary also joined the community in Jerusalem;

- the so-called "Hellenists", mentioned in Acts 6:1; they belonged to those Jews from the Diaspora who returned to Jerusalem to live there. A certain number of these returnees joined the young Christian community. Obviously this group grew rather quickly and became a distinctive sub-group within the community. The list of 7 persons handed down in Acts 6:5 - with Stephen at the first place; can fairly be considered as the list of the leading body of the "Hellenists";

- apart from these two groups, other persons also joined the community, for example Barnabas, who later on was to become the leading figure in the community of Antioch.

The Twelve all came from Galilee and soon were not representative of the quickly growing community as a whole, because it was not possible to widen the group of the Twelve in order to include, for example James or Stephen or Barnabas. This reason makes us understand why the group of the Twelve quickly lost its leading role in the community of Jerusalem. So James, the son of Zebedee was not replaced after his killing between 41 and 44 AD. And when in 49 AD the leaders of the community of Antioch, Barnabas and Paul, went to Jerusalem to settle the conflict regarding the preaching of the Gospel to nonJews, they did not meet the Twelve as leading body of the community of Jerusalem, but they talked to the three "pillars", the st ul oi (Gal 2:9). This means that the community in Jerusalem was no longer directed by the Twelve but by what could be termed a Triumvirate or a Troika.

The Triumvirate was formed by James, Peter (here called Cephas) and John. James, who is mentioned in the first position, was the brother of the Lord; and from 1 Corinth 15:7 we can fairly deduce that he was a leading person within the group of the Apostles in Jerusalem, similar to Peter, who was the leading person within the group of the Twelve. Peter, who was Apostle (GI 1:18-19) and at the same time head of the Twelve, held the middle position. The third person of the Triumvirate was John, son of Zebedee, a prominent member of the Twelve (Mk 1:19; 5:37; 9:2; 10:35-41).

This reflects the development of the community in Jerusalem until 49 $A D$, but we know that this development continued. The importance of the 
Twelve waned and when in 56 AD Paul visited Jerusalem James was the only leading person, and had definitively replaced Peter (Ac 21:18). ${ }^{22}$

Now let us turn to the lists of names that occur in the New Testament. ${ }^{23}$ There are four lists altogether (Mk 13:16-19; Mt 10:2-4; Lk 6:14-16: Ac 1: 13). In all the lists Peter is mentioned in the first position and Judas Iscariot in the last (besides Ac 1:13). The other names differ in order, but not significantly so. Apart from the differences in order, ten names are identical in all the lists. Differences concerning the names exist between the lists in Mark 3 and in Matthew 10, on the one hand, and those in Luke 6 and in Acts 1, on the other hand. The one obvious difference pertains to the name of Thaddaeus, which is mentioned by Mark (and Mathew) but which does not appear in Luke (and in Ac). In the Lukan lists Judas, son of James is mentioned instead of Thaddaeus. Moreover, there is a difference with regard to the "Simon" mentioned in the second half of all the lists: In Mark (and in Mt) he is called "Simon the Cananaean", while in Luke (and Ac) he is referred to as "Simon the Zealot."

When the Evangelists wrote their gospels during the last decades of the first century, they no longer had a firm idea of the Twelve and to a greater or lesser extent identified them with the group of the Apostles ${ }^{24}$ which was a distinctive group alongside the Twelve at the outset. This can be deduced from the two different statements about the appearances of the Lord in 1 Corinth 15, verse 5 concerning the appearance to Peter and the Twelve (wf qh Khf aæeita toi $\sim$ dwdeka / "he appeared to Cephas, then to the Twelve") and in verse 7 to James and "the Apostles altogether" (ep eit a wf $q h$ Fak wbwó eit a t oi a p os t ovoi pas̀ in / "there upon he appeared to James, then to the Apostles altogether"). The Evangelists identified both groups, both which did not exist at their time any longer. The way in which Luke handled the matter is most interesting - he aimed at a mutual and exclusive identification of the Twelve and the Apostles (cf Ac 1:26; 6:2, 6). But it was impossible to count Paul among those Twelve who had accompanied Jesus from Galilee to Jerusalem (cf Ac 1:21-26). Therefore, with the exception of two instances (Ac 14:4, 14), he even denied Paul the title of "Apostle".

\footnotetext{
${ }^{22}$ For details of the history of James, see Pratscher (1987); Painter (1997).

${ }^{23}$ See the lists provided at the end of the article.

${ }^{24}$ This may already be the case in Mark 3:14 if it is read according to the old manuscripts a, $\mathrm{B}, \mathrm{Q}$ et ceterakai; ep oiks en dwdeka, ouł kai; apostovou whomas en (and he made Twelve, whom he also named apostles"); the same remark occurs in Luke 6:13. Matthew 10:2 has the clear expression: oil dwdek a ap ost ol oi.
} 
This was a somewhat radical solution which the churches did not accept in later times. When, in later centuries, lists of the "Twelve Apostles" were established, the identification of the Twelve and the Apostles was adopted, but with the inclusion of Paul. The inclusion of Paul was achieved by omitting Judas, respectively the by-elected Matthias (Ac 1:15-26). ${ }^{25}$ This was a common development in the churches of the East and the West. In addition, the Greek speaking church included Mark and Luke ${ }^{26}$ for obvious reasons: The New Testament lists already contained Matthew and John, to whom two of the Gospels were ascribed. By including Mark and Luke, all four evangelists thus became represented in the list. In order to achieve this, two other unimportant names from the second half of the New Testament lists were omitted, namely those of James, son of Alphaeus, and Thaddaeus (or Judas, son of James, who is mentioned in Lk 6 and Ac 1 instead of Thaddaeus).

To summarise: The historical role of the Twelve was limited to a short period. For this reason the authors of the Gospels had no idea of the historical function of the Twelve. As institution of pre-Easter origin the Twelve represented the new eschatological people of God initially gathered by Jesus, then re-convened in the name of the risen Lord. The more the early Christian community in Jerusalem grew, the more the Twelve lost their importance. Almost 20 years later, in $49 \mathrm{AD}$, the leading body of the community was no longer the group of the Twelve but a group of three people, called the "pillars" (GI 2: 9). Two of these "pillars" (Peter and John) were members of the former group of the Twelve, the third, in Galatians 2:9 mentioned in the first position, was James, the brother of the Lord. Few years later, in $56 \mathrm{AD}$, it was only James who was the head of the community in Jerusalem. The Twelve, we must conclude, definitely had lost their function. Another 20 or 30 years later the Twelve entered a new carrier on the literary level in the Synoptic Gospels, now being merged with another group of the first decades that did not exist no longer either, the Apostles. This identification produced new problems because now Paul hat to be integrated in the group of the Twelve. Luke tried to avoid this consequence but at this point he was not successful. All lists established in later centuries by the Latin and Greek-speaking churches

\footnotetext{
${ }^{25}$ The row of Apostles in the Cathedral San Vitale in Ravenna (Italy) which dates back to the middle of the $6^{\text {th }}$ century provides an early example. In the arch in front of the presbyterium is a chain of medallions: In the central position is a medallion of Christ with on each side seven other medallions, six Apostles and (in the last position) one Saint. Peter and Paul are placed on either side of Christ. When both rows are joined alternately, the same list emerges as in the Sacramentarium Gelasianum (from the $8^{\text {th }}$ century): There Peter and Paul are at the top of the list, followed by Andreas (Andrew), Jacubus (James), Johannes (John) et cetera (see Mohlberg 1971:238).

${ }^{26}$ As for example in Ps-Chrysostomos, in XII Apostolos (Migne 1862:495).
} 
included Paul in the number of the "12 Apostles" despite the fact that he never had been a disciple of the historical Jesus.

Lists of the Twelve in the New Testament and in the tradition of the church

\begin{tabular}{|c|c|c|c|c|c|c|}
\hline & Mt 10:2-4 & Mk 3:16-19 & Lk 6:14-16 & Acts 1:13.26 & \begin{tabular}{l|} 
Ravenna, San \\
Vitale (cf \\
Sacramentariu \\
m Gelasianum)
\end{tabular} & $\begin{array}{l}\text { Ps-Chrysosto- } \\
\text { mos, In XII } \\
\text { Apostolos }\end{array}$ \\
\hline 1 & $\begin{array}{l}\text { Simwn of } \\
\text { l egomeno } \\
\text { P etro }\end{array}$ & $\begin{array}{l}\text { (S imwn) } \\
\text { P etro }\end{array}$ & $\begin{array}{l}\text { Simwn, of } \\
\text { kai; P etro }\end{array}$ & P etro & Petrus & P etro \\
\hline 2 & $\begin{array}{l}\text { 原 ndrea } ~ \\
\text { of a del f or } \\
\text { a uf ou' }\end{array}$ & $\begin{array}{l}\text { Fa k wbo } \\
\text { ol t ou' } \\
\text { Z ebedaiou }\end{array}$ & $\begin{array}{l}\text { 㕅 ndrea } 0 \text { J } \\
\text { a jlel f o; } \\
\text { a uf ou' }\end{array}$ & Ewa anh & Paulus & P aulo \\
\hline 3 & $\begin{array}{l}\text { Jakwbo } \\
\text { of tou' } \\
\text { Z ebedaiou }\end{array}$ & $\begin{array}{l}\text { Fewamnh } \\
\text { of a jel f o; } \\
\text { tou' Eak wbou }\end{array}$ & Fa k wbo & Fak wbo & Andreas & 伯ndrer \\
\hline 4 & $\begin{array}{l}\text { Ewa unh } \sim \text { ol } \\
\text { a del } f \text { o; } \\
\text { a uf ou' }\end{array}$ & 有 $n d r$ ea & Fwa anh & 伯 $n d r$ er $~$ & Jacobus & S imwn \\
\hline 5 & Fivippo & Fivippo & Fivippo & Fivippo & Johannes & Q wma 〜 \\
\hline 6 & Barqol omaiò & Barqol omaió & Barqol omaió & Q wma 〜 & Philippus & Fa kwbo \\
\hline 7 & Q wma $\sim$ & Maqqaior & Maqqaió & Barqol omaiò & Bartholomeus & Marko \\
\hline 8 & $\begin{array}{l}\text { M aqqaió } \\
\text { of tel wah }\end{array}$ & Q wma i & Qwma $\sim$ & Maqqaió & Thomas & Louka \\
\hline 9 & $\begin{array}{l}\text { Ea k wbo } \\
\text { of t ou } \\
\text { ï I f a i ou }\end{array}$ & $\begin{array}{l}\text { Fea k wbo } \\
\text { of tou' } \\
\text { iA I f a iou }\end{array}$ & $\begin{array}{l}\text { Fa k wbo } \\
\text { IA I f a iou }\end{array}$ & $\begin{array}{l}\text { Fakwbo } \\
\text { İA I f a i ou }\end{array}$ & Mattheus & Maqqaiò \\
\hline 10 & Q addaiò & Qaddaiò & $\begin{array}{l}\text { Simwn ol } \\
\text { kal oumeno } \\
\text { Zhl wt h } \forall\end{array}$ & $\begin{array}{l}\text { Simwn ol } \\
\text { zhl wt h } \forall\end{array}$ & $\begin{array}{l}\text { Jacobus } \\
\text { Al(phaeus) }\end{array}$ & Ewamnh \\
\hline 11 & $\begin{array}{l}\text { S imwn of } \\
\text { K a na naiò }\end{array}$ & $\begin{array}{l}\text { Simwn ol } \\
\text { K ananaiò }\end{array}$ & $\begin{array}{l}\text { Eouda } \\
\text { Eak kbou }\end{array}$ & $\begin{array}{l}\text { Fouda } \\
\text { Fak wbou }\end{array}$ & Thaddeus & B arqol omaiò \\
\hline 12 & $\begin{array}{l}\text { FEouda 0l } \\
\text { FEskariwth }\end{array}$ & $\begin{array}{l}\text { Fouda } \\
\text { Esk kariwg }\end{array}$ & $\begin{array}{l}\text { Eouda } \\
\text { Esk k a i wa }\end{array}$ & Maqqia & $\begin{array}{l}\text { Simon } \\
\text { Chan(anaeus) }\end{array}$ & Fivippo \\
\hline
\end{tabular}

Lists of the Twelve in the New Testament and in the tradition of the church

\begin{tabular}{|l|l|l|l|l|l|l|}
\hline & Mt 10:2-4 & Mk 3:16-19 & Lk 6:14-16 & Acts 1:13.26 & $\begin{array}{l}\text { Ravenna, San } \\
\text { Vitale (cf. } \\
\text { Sacramentarium } \\
\text { Gelasianum) }\end{array}$ & $\begin{array}{l}\text { Ps-Chryso- } \\
\text { stomos, In } \\
\text { XII apostolos }\end{array}$ \\
\hline 1 & $\begin{array}{l}\text { Simon, who } \\
\text { is called } \\
\text { Peter }\end{array}$ & $\begin{array}{l}\text { Simon / } \\
\text { Peter }\end{array}$ & $\begin{array}{l}\text { Simon / } \\
\text { Peter }\end{array}$ & Peter & Peter & Peter \\
\hline 2 & $\begin{array}{l}\text { Andrew, his } \\
\text { brother }\end{array}$ & $\begin{array}{l}\text { James, son } \\
\text { of Zebedee }\end{array}$ & $\begin{array}{l}\text { Andrew, his } \\
\text { brother }\end{array}$ & John & Paul & Paul \\
\hline
\end{tabular}


The origin, function and disappearance of the "Twelve"

\begin{tabular}{|l|l|l|l|l|l|l|}
\hline 3 & $\begin{array}{l}\text { James, son } \\
\text { of Zebedee }\end{array}$ & $\begin{array}{l}\text { John, the } \\
\text { brother of } \\
\text { James }\end{array}$ & James, & James & Andrew & Andrew \\
\hline 4 & $\begin{array}{l}\text { John, his } \\
\text { brother }\end{array}$ & Andrew & John, & Andrew & James & Simon \\
\hline 5 & Philip & Philip & Philip & Philip & John & Thomas \\
\hline 6 & Bartholomew & Bartholomew & Bartholomew & Thomas & Philip & James \\
\hline 7 & Thomas & Matthew & Matthew & Bartholomew & Bartholomew & Mark \\
\hline 8 & $\begin{array}{l}\text { Matthew the } \\
\text { tax collector }\end{array}$ & Thomas & Thomas & Matthew & Thomas & Luke \\
\hline 9 & $\begin{array}{l}\text { James, son } \\
\text { of Alphaeus }\end{array}$ & $\begin{array}{l}\text { James, son } \\
\text { of Alphaeus }\end{array}$ & $\begin{array}{l}\text { James, son } \\
\text { of Alphaeus }\end{array}$ & $\begin{array}{l}\text { James, son } \\
\text { of Alphaeus }\end{array}$ & Matthew & Matthew \\
\hline 10 & $\begin{array}{l}\text { Thaddaeus } \\
\text { Cimon the } \\
\text { Cananaean }\end{array}$ & $\begin{array}{l}\text { Simon, who } \\
\text { was called } \\
\text { the Zealot }\end{array}$ & $\begin{array}{l}\text { Simon the } \\
\text { Zealot }\end{array}$ & $\begin{array}{l}\text { James, son of } \\
\text { Alphaeus }\end{array}$ & John \\
\hline 11 & $\begin{array}{l}\text { Simon the } \\
\text { Cananaean }\end{array}$ & Thaddaeus & $\begin{array}{l}\text { Judas, son } \\
\text { of James }\end{array}$ & $\begin{array}{l}\text { Judas, son } \\
\text { of James }\end{array}$ & Thaddaeus & Bartholomew \\
\hline 12 & $\begin{array}{l}\text { Judas } \\
\text { Iscariot }\end{array}$ & $\begin{array}{l}\text { Judas } \\
\text { Iscariot }\end{array}$ & $\begin{array}{l}\text { Judas } \\
\text { Iscariot }\end{array}$ & Matthias & $\begin{array}{l}\text { Simon the } \\
\text { Cananaean }\end{array}$ & Philip \\
\hline
\end{tabular}

\section{Works consulted}

Becker, J 1996. Jesus von Nazareth. Berlin: De Gruyter.

Best, E 1978. Mark's use of the Twelve. ZNW 69, 11-35.

Bultmann, R [1931] 1964. Die Geschichte der synoptischen Tradition. 4.Aufl.

Göttingen: Vandenhoeck \& Ruprecht.

Bultmann, R 1958. Theologie des Neuen Testaments. 3.Aufl. Tübingen: Mohr

Siebeck.

Fee, G D 1987. The first epistle to the Corinthians. Grand Rapids, MI: Eerdmans.

Fitzmyer, J A 1984. The Gospel according to Luke (X-XXIV). Garden City:

Doubleday. (Anchor Bible 28a.)

Gnilka, J 1978. Evangelium nach Markus, Band 1. Zürich: Benzinger/Neukirchen-

Vluyn: Neukirchener Verlag.

Goertz, H-J 1995. Umgang mit der Geschichte. Reinbek: Rowohlt.

Heil, C 1998. Q 22:28, 30. You will judge the twelve tribes of Israel, in Documenta Q:

Reconstructions of $Q$ through two centuries of Gospel research: Excerpted, sorted and evaluated. Leuven: Peeters Press.

Holtz, T 1980. s v dwdek a. Exegetisches Wörterbuch zum Neuen Testament, Band 1, 874-880. Stuttgart: Kohlhammer.

Klauck, H-J 1989. Die Auswahl der Zwölf (Mk 3, 13-19), in Klauck, H-J, Gemeinde Amt - Sakrament, 131-136. Würzburg: Echter.

Klein, G 1961. Die zwölf Apostel. Göttingen: Vandenhoeck \& Ruprecht.

Koch, D-A 1975. Die Bedeutung der Wundererzählungen für die Christologie des

Markusevangeliums. Berlin: De Gruyter.

Koch, D-A 1995. Zwölferkreis und Gottesvolk, in Brändle, W et al (Hrsg), Geist und

Kirche: Festschrift E Lessing, 1-20. Franfurt: Lang.

Koch, D-A [2005]. Zwölferkreis, in Religion in Geschichte und Gegenwart, Band 8.

4.Aufl. Tübingen: Mohr Siebeck. 
Kraft, R A 1965. The Apostolic Fathers: A new translation and commentary, vol 3:

Barnabas and Didache. Toronto: Nelson.

Lateiner, D 1989. The historical method of Herodotus. Toronto: University of Toronto Press.

Lendle, O 1992. Einführung in die griechische Geschichtsschreibung. Darmstadt: Wissenschaftliche Buchgesellschaft.

Luz, U 1997. Das Evangelium nach Matthäus, Band 3. Zürich: Benzinger / Neukirchen-Vluyn: Neukirchener Verlag.

Meier, J P 1997. The circle of the Twelve: Did it exist during Jesus' public ministry?. JBL 116, 635-672.

Meister, K 1997. Die Interpretation historischer Quellen. Schwerpunkt: Antike, Band 1. Paderborn: Schöningh.

Meister, K 1998. s v Herodotos, in Der Neue Pauly: Enzyklopädie der Antike, Band 1, 469-475. Stuttgart: Metzler.

Migne, J-P (ed) 1862. Ps-Chrysostomus, in XII Apostolos. Patrologia Graeca 59, 495-498. Paris: Migne.

Mohlberg, K 1971. Das Fränkische Sacramentarium Gelasianum. 3. Aufl. Münster: Aschendorff.

Painter, J 1997. Just James. Columbia, SC: University of South Carolina Press.

Pratscher, W 1987. Der Herrenbruder Jakobus und die Jakobustradition. Göttingen: Vandenhoeck \& Ruprecht.

Prostmeier, F 1999. Der Barnabasbrief. Göttingen: Vandenhoeck \& Ruprecht.

Rebenich, S 2000. s v Historismus, in Der Neue Pauly: Enzyklopädie der Antike, Band 14, 469-485. Stuttgart: Metzler.

Robinson, J M et al 2000. The critical edition of Q. Leuven: Peeters Press.

Roloff, J 1993. Die Kirche im Neuen Testament. Göttingen: Vandenhoeck \& Ruprecht.

Roose, H 2004. Eschatologische Mitherrschaft. Göttingen: Vandenhoeck \& Ruprecht.

Rüsen, J 1983. Historische Vernunft. Göttingen: Vandenhoeck \& Ruprecht.

Rüsen, J 1986. Rekonstruktion der Vergangenheit. Göttingen: Vandenhoeck \& Ruprecht.

Schenke, L 1990. Die Urgemeinde. Stuttgart: Kohlhammer.

Schneemelcher, W 1981. Das Urchristentum. Stuttgart: Kohlhammer.

Schrage, W 2001. Der erste Brief an die Korinther, Band 4. Zürich:

Benzinger/Neukirchen-Vluyn: Neukirchener Verlag.

Schulz, S 1972. Q. Die Spruchquelle der Evangelisten. Zürich: Theologischer Verlag.

Stock, K 1975. Boten aus dem Mit-Ihm-Sein: Das Verhältnis zwischen Jesus und den Zwölf nach Markus. Rom: Biblical Institute Press.

Theissen, G \& Merz, A 1997. Der historische Jesus: Ein Lehrbuch. 2.Aufl. Göttingen: Vandenhoeck \& Ruprecht.

Trilling, W 1977. Zur Entstehung des Zwölferkreises, in Schnackenburg, $\mathrm{H}$ et al (Hrsg), Die Kirche des Anfangs. Festschrift H Schürmann, 201-222. Freiburg: Herder.

Tuckett, C 1996. Q and the history of early Christianity. Edinburgh: T \& T Clark. 